\title{
A FUNÇÃO SOCIAL DA POSSE E SUA REPERCUSSÃO NO INSTITUTO DA USUCAPIÃO DE IMÓVEIS PÚBLICOS
}

\section{THE SOCIAL FUNCTION OF POSSESSION AND ITS REPERCUSSION AT THE INSTITUTE OF THE USUCAPION OF PUBLIC PROPERTIES}

\author{
Juventino Gomes de Miranda Filho* \\ Elissandra Assis Moura Campos de Miranda ${ }^{* *}$
}

\begin{abstract}
RESUMO
No presente artigo analisam-se as características dos imóveis públicos e suas especificidades em relação aos imóveis particulares. $O$ instituto de usucapião e o princípio da imprescritibilidade são investigados à luz da Constituição da República Federativa do Brasil de 1988 e da Codificação Civil Brasileira, além da vastidão jurisprudencial e do Enunciado no. 340 da Súmula do STF. As análises sustentam-se em bases dialéticas e em vista da Função Social da posse.
\end{abstract}

Palavras-chave: Função Social. Imóveis Públicos. Ortodoxia. Posse. Usucapião.

\begin{abstract}
This article analyzes the characteristics of public properties and their specificities in relation to private properties. The usucapion institute and the principle of imprescriptibility are investigated in the light of the 1988 Constitution of the Federative Republic of Brazil and of the Brazilian Civil Codification, in addition to the vast jurisprudence and Statement no. 340 of the STF Summary. The analyzes are based on dialectical bases and in view of the Social Function of possession.
\end{abstract}

Keywords: Social Function. Public Real Estate. Orthodoxy. Possession. Usucapião.

\section{INTRODUÇÃO}

É recorrente a sustentação graças à qual os imóveis públicos, por ostentarem essa condição, possuem algumas características que os distinguem dos imóveis particulares. Uma dessas singularidades pode ser vislumbrada pela imprescritibilidade, que se traduziria na impossibilidade de sua usucapibilidade. Em favor desse tradicional e ortodoxo entendimento alinham-se diversos textos legais, capitaneados pela própria Constituição Federal, através dos artigos 183, §3º e 191, Parágrafo Único, subsequenciados pelo Código Civil (art. 102), pela vastidão da legislação extraordinária e com sustentação jurisprudencial advinda do enunciado

Artigo submetido em 29 de março de 2021 e aprovado em 03 de setembro de 2021.

* Doutor em Direito Privado e Mestre em Direito Processual, ambos os títulos pelo Programa de Pós-Graduação em Direito da PUC Minas. E-mail: jgmirandafilho@yahoo.com.br

** Oficiala do Serviço de Registro Civil das Pessoas Naturais de Barroso-MG. Pós-graduação lato sensu em Direito Notarial e registral. E-mail: elissandramoura@gmail.com 
n 340 da Súmula do STF. Se no plano do direito positivo e no plano do direito pretoriano esse entendimento ganha majoritarismo, também na vertente doutrinária o entendimento preponderante é o mesmo. Há enorme messe de doutrinadores de escolas, para não dizer quase todos, a sustentar que os imóveis públicos, só por serem públicos, destinam-se ao interesse público. Segundo essa premissa, por isso mesmo já trazem imanente a ostentação da função social.

Essa linha de raciocínio, basicamente, é utilizada para sustentar a proverbial impossibilidade da consumação da usucapião incidente sobre a propriedade pública. E em se tratando de avassaladora corrente legal-doutrinário-jurisprudencial, esses posicionamentos patenteiam-se herméticos, obstando a abertura dialética.

O presente artigo investiga princípios, normas e possibilidades.

\section{A FUNÇÃO SOCIAL E O INSTITUTO DA POSSE. UM RÁPIDO HISTÓRICO- CULTURAL}

Inobstante tanta ortodoxia, o que se entende é que toda propriedade, seja pública, seja privada, deve atender à função social. Esse entendimento resulta da necessidade da facção de uma releitura do instituto da posse, objetivando à superação do modelo codificado liberal, questionando o positivismo pela perspectiva fundada na reinterpretação hermenêuticosistemática constitucional e infraconstitucional abertas, em busca de efetiva concretude, cujo fundamento jurídico-social seja a pessoa humana e não o indivíduo patrimonialista.

Por essa ótica, novas concepções de institutos, como a da posse pour cause de suas vertiginosas transformações, exigem um novo pensar. Daí nasceram a necessidade e o esforço para estimular e reorganizar a utilização das coisas para aquelas pessoas hipossuficientes, objetivando proporcionar um uso melhor da terra, rural e urbana.

Dificultar o acesso à propriedade pelo caminho da posse-fruição é confiscar numa ilha solitária de pobreza um sem número de vocacionados para a terra rural e moradia urbana, embora em meio a um vasto oceano de prosperidade material.

Por isso a abordagem do instituto da função social da posse à luz da supralegalidade privilegia os valores supremos enunciados no Preâmbulo da Constituição de 1988, eles próprios enunciadores dessa supralegalidade que antecedeu ao próprio texto constitucional e sua promulgação, pois sua existência precede à constituinte. Tais valores supremos são valores suprapositivos, supralegais, especialmente em temas da supremacia da dignidade da pessoa humana, da cidadania, do bem-estar, do desenvolvimento, do progresso, da função social, como elementos estruturadores da patrimonialidade, da extrapatrimonialidade, da propriedade e, sobretudo, da posse.

Temas tais quais esses, sujeitos a sempre profícua evolução, não ficam nem podem ficar estagnados no positivismo amorfo, ainda que sob a vestimenta constitucional. Tais valores preexistem às próprias disposições constitucionais, pois são imanentes a toda ordem jurídica.

Comecemos focando disposições como as dos arts. 183, §3 e 191, Parágrafo Único, da Constituição; do art. 102 do Código Civil e tantas outras que lhes são semelhantes, proibitivas da usucapião incidente sobre imóveis públicos, por confrontarem e até infringirem os objetivos do Estado Democrático de Direito, instituídos pela mesma Constituição (Preâmbulo e art. $1^{\circ}$ ), mas axiologicamente superiores às disposições literais, produto do positivismo. Os objetivos ascendem e transcendem à literalidade.

Embora a ideia de um positivismo exacerbado, extremo, mesmo em termos constitucionais, extravase o conteúdo jurídico sustentador dos valores supremos, essa constatação impõe que se faça a distinção entre direitos, direito vigente, e lei escrita.

Embora haja lições às centenas, centradas na indiferença da função social dos institutos, especialmente da posse, embora seja proverbialmente repetida a impossibilidade de 
consumação da usucapião de imóveis públicos insuscetíveis de posse e de incidência da usucapião porque efetiva e concretamente prostam-se a um inquestionável interesse público (como o ar atmosférico, o alto mar, as áreas de proteção ambiental e tantas outras) e alguns até a interesse e salvaguarda das gerações futuras, não se pode dizer o mesmo, generalizadamente, de imóveis sobre os quais inexista um interesse público concreto, efetivo, real e não abstrato. Nesses casos atuará a função social estruturante, compartilhadora da própria estrutura da ideia de posse, exigindo sua efetivação e possibilitando a posse e atuação de seu maior efeito: a usucapião.

Essa concretização nasce da interpretação e busca da revelação do pensamento que anima as palavras e o espírito contidos no ordenamento jurídico.

É preciso convir que a Lei Fundamental elegeu valores maiores, os quais destinou à concretização dos transcendentes escopos. E sobre ter criado a propriedade numérica, erigiu a moradia e as áreas de plantio à categoria de direito fundamental, filiando-as à dignidade da pessoa humana, à cidadania. A concretização desses ascéticos objetivos dar-se-á pela posse funcionalizada, meio pacífico, por excelência, de atingi-los.

É por isso que, no confronto entre um mero, genérico e abstrato interesse público e os valores maiores referidos, resulta induvidoso que estes sobrepujem aqueles, principalmente esses últimos que também recebem a chancela do interesse público que o Estado tem o dever de assegurar e resguardar.

Num breve enfoque sobre as obras clássicas sustentadoras da inusucapibilidade de imóveis públicos e do desprezo relativo à função social da posse, é proveitosa a invocação de Fernando Luso Soares (1996), em seu prefácio à obra de Manoel Rodrigues, justificando a proposta de atualização daquela obra clássica:

As obras clássicas devem ser objeto de periódica releitura. Só assim em cada novo ciclo da progressão civilizacional elas poderão confrontar-se com as interrogações, as perplexidades, as soluções as novidades que lhes sucederam no tempo.

E o fundamento irretorquível vem a seguir:

Toda e qualquer obra de ciência tem seu lugar num determinado momento de evolução cientifica e, como tal, ela insere-se num processo, não precisando que a situem ou rodeiam de quaisquer constelações. (SOARES, 1996, p. 11)

Nada mais natural: o direito é dinâmico e deve refletir a realidade da vida social. Bem por isso evolui com ela ou, na pior das hipóteses, procura acompanhar essa evolução, ainda que em ritmo de progressão aritmética.

Nesse sentido também observou Frederico Barbosa Gomes (2007), apresentando a obra de Álvaro Ricardo de Souza Cruz, ao dizer que "a desconexão entre o que se estuda e a realidade que se pretende alterar, entre tantos outros problemas, marca, de forma indelével, o atual contexto brasileiro, a ponto de disseminar a perigosa dúvida acerca da viabilidade do projeto democrático por essas terras.” (GOMES, 2007, p.11-12)

Adverte Frederico Barbosa Gomes que a "revolução copernicana" operada no estudo e na pesquisa do direito revela não ser na fria observação de códigos e leis que se encontrarão soluções para os problemas sociais e comportamentais que afligem os homens. O homem se descobriu "como ser hermenêutico, histórico, dotado e limitado, capaz de pensar saídas para os problemas" (GOMES, 2007, p.12).

Outro não é o entendimento de GADAMER (2001, p. 461), para quem "um texto legal tem de ser compreendido em cada instante, isto é, em cada situação concreta de uma maneira nova e distinta". Aqui, compreender é sempre também aplicar. 
Consentâneo com o que subministra a experiência, os métodos interpretativos devem estar atentos às transformações por que passou o mundo, especialmente a partir da Revolução Industrial.

Quanto à tese na órbita da posse, restou mudado o centro gravitacional. As coisas desgarram-se do ter para abraçar o ser, lugar ocupado pelo ser humano, enquanto pessoa, como menciona Cesar Fiuza: "Com direito à dignidade, à promoção espiritual, social e econômica. Fala-se, pois, em função social do contrato, da propriedade. Fala-se em despatrimonialização do direito privado" (2007, p. 96),

Como síntese da vivência, a experiência permite a contemporaneidade das ideias antigas, vividas, que constituem motivo de afeiçoamento, pois como observou Feyerabend (2007, p. 26), "não há nenhuma ideia, por mais antiga e absurda, que não seja capaz de aperfeiçoar nosso conhecimento".

Enfim, os novos tempos nos convidam à busca incessante da superação do conhecimento ingênuo, fragmentário e conservador, e à transformação do senso comum em bom senso, prudência, razoabilidade, na busca de condições teóricas e práticas para a efetivação do direito, enquanto instrumento de cidadania. A esse propósito, prontifica Silvia Pimentel: "O Direito, de hoje, é aquele que historicamente construímos e que será, amanhã, aquele que viermos a construir". (PIMENTEL, 2010, p. 15). Parece inquestionável esse proceder, porque é o que dita o que ordinariamente ocorre.

A interdisciplinaridade pretendeu ultimar com a ideia do conhecimento compartimentado porque nele reside um "símbolo da fragmentação da realidade e o surgimento de uma inteligência esquizofrênica, que impede uma apreensão abrangente do mundo" (ALMEIDA PRADO, 2010, p. 170).

Thomas Kuhn observou em 1963, em A estrutura das Revoluções Científicas, que a ciência se desenvolve por meio da ruptura e construção do conhecimento. E criticou, veementemente, a tradição positivista.

\begin{abstract}
Inobstante a desmedida importância do Iluminismo, que enalteceu o respeito e o culto ao homem, tendo por ideário o progresso e a liberdade, que sustentou sua luta contra as religiões e as superstições e, além disso, concebeu o saber estribado na experiência e na estrita observância do método científico, seu instrumento foi a Enciclopédia (ou Dictionnaire Raisonné des Sciences, des Arts, et des Métiers, dirigida por D' Alembert e Diderot), de longa elaboração ao longo de 20 anos (até 1772, quando encerrou seu $17^{\circ}$ volume). Seu objetivo: uma tentativa de síntese do conhecimento, contando com a colaboração de 139 luminares, entre eles Montesquieu (leis), Helvetius (matemática), Lamarek (botânica), Rousseau (música), Voltaire (verbetes sobre história, elegância, espírito, imaginação).
\end{abstract}

No ir e vir da história, um século depois do Iluminismo e de seu instrumento maior, a Enciclopédie, dirigida por D`Alembert e Diderot, como uma tentativa de síntese do conhecimento humano, a cultura se fragmentaria, com o advento das especializações típicas do nosso tempo. A complexidade do conhecimento, nunca antes ocorrida torna, impensável que uma pessoa possa ser, como os sábios de outrora, conforme Bertrand Russel (1961) ${ }^{1}$, detentora de uma sabedoria ampla. Mas isso não justifica que os especialistas em partes sejam ignorantes em relação ao todo.

\footnotetext{
${ }^{1}$ Conforme B. Russel, Leonardo da Vinci transitava por diversos ramos do conhecimento: foi pintor, escultor engenheiro, arquiteto, escritor, além de conhecedor de Anatomia, Física, Botânica e Matemática. Relembre-se Gottfried Willhelm Leibniz, que foi filósofo, porém fez descobertas em Matemática, História, Linguística; foi físico, diplomata, musicólogo, tradutor, jurista, engenheiro, poeta, zoólogo, antropólogo, geólogo, paleontólogo, antropólogo, embriologista, cosmólogo, filósofo, do direito. E, no dizer seguro de Bertrand Russel "foi uma das mais altas inteligências de todos os tempos".
} 
O revisionismo é e deve ser permanente no sentido de repensar o direito. E ele mais se intensifica em temas como os de exclusão da cidadania de pessoas desfavorecidas, vitimadas pela carência ensejadora da chamada crise de efetividade dos direitos sociais, que propicia o surgimento de ordens paralelas, como no caso das favelas e aglomerados, antes fenômeno detectado nas grandes metrópoles, hoje oceanizado Brasil afora. E no caso dos sem-terra e dos sem-teto, há vetores de violência atribuída a reivindicações inatendidas.

O tema da função social tem vastíssimo alcance, abrangendo o direito constitucional, no qual deita sua origem, o direito privado e o direito público, irradiando-se pelo contrato, a economia, a empresa, a propriedade intelectual, o direito tributário, o biodireito, a arbitragem. Em síntese, a sua abrangência reserva-lhe papel de ampla importância no ordenamento jurídico em geral.

No início do século XX, Duguit (1912, p. 24-25) sustentou que a função social extinguiu os direitos subjetivos porque os indivíduos eram apenas aqueles que cumprem funções sociais. Daí a sua proposição de substituição das expressões 'poder legislativo', 'poder judiciário' e 'poder executivo' por funções. Já na obra Les transformations, Duguit explicita as razões de seu posicionamento:

\footnotetext{
A função social desponta como cláusula geral, regedora de toda atividade econômica, servindo de balizamento constitucional do direito fundamental, quer da posse, quer da propriedade, delimitando seu conteúdo, estruturalmente, por isso que, como decorre desde as ordenações do Reino e legislação extravagante, com repercussão na Constituição do México (1917) e na de Weimar (1919): A propriedade e (com ela ou sem ela) a posse obriga! (DUGUIT, 1926, p. 09)
}

Essa Constituição, como se sabe, transformou a estrutura do direito de exercer esses direitos (a posse e a propriedade), de modo a atingir determinadas finalidades: a propriedade deixa de ser um direito absoluto e a posse autonomiza-se e ganha independência como instrumento de pacificidade e de acesso à moradia e à utilização agrícola.

Essa concepção nasceu justamente do estado intervencionista, com a constitucionalização da ordem econômica, perdendo prestígio o extremado individualismo reinante no século XIX, em razão de uma nova realidade social. Essa realidade foi trazida pela miséria operária do início da Revolução Industrial; pela distribuição de renda, quando regida unicamente pelas leis do mercado; pela grande crise de 1929, que ocasionou a queda da bolsa de Nova York, conforme Didier (2008, p. 13).

De relevância é a constatação da função social da posse e da propriedade vincularem-se aos direitos fundamentais, a partir do disposto no art. $5^{\circ}$, inciso XXIII e art. 170 , inciso III da Constituição da República Federativa do Brasil de 1988.

A função social da posse não encontrou espaço apenas na visão ortodoxa, pois esta, envolta em sua tradicionalidade, conecta a posse umbilicalmente à propriedade, integrando seu conceito, embora como elemento dinâmico da propriedade, tanto na ótica de Savigny como na visão de Ihering. Mas a evolução colocou a função social como elemento estruturante do direito de propriedade, integrando, assim, seu próprio conceito e determinando-lhe deveres fundamentais. A posse sintetiza, por sua natureza, as vantagens de seu dinamismo, enquanto a propriedade permanece como um direito meramente abstrato, exatamente porque todo direito é abstrato.

Não há dúvida de que a CF/1988, no que concerne à função social da posse (e a da propriedade), fulcra-se na adequada utilização dos bens em proveito da coletividade, dispondo assim tanto no art. $182, \S 2^{\circ}$ (quanto à propriedade urbana) quanto no art. 186 , se rural. E num vislumbre, ainda que perfunctório, depreende-se do étimo 'utilização', que guarda em si, até semanticamente, o sentido de aplicação, aproveitamento, emprego, uso, significações próprias do instituto da posse como exercício fático de poderes da propriedade (art. $1196 \mathrm{cc}$ ): direito de 
usar (uso); direito de gozar (gozo) (HOUAISS, 2009, p. 2817). E não se deve olvidar que as disposições constitucionais do art. $182, \S 2^{\circ}$ e 186 tipificam princípios, enquanto as dos art. $183, \S 3^{\circ}$ e 191 , parágrafo único, ensejam regras ${ }^{2}$.

Destinando-se a função social à efetiva e adequada utilização dos bens para a satisfação das necessidades, por óbvio ela limita o conceito do direito de propriedade. O fenômeno real latente na posse é quase sempre visível e tangível. A representação mental faz-se sumamente facilitada na posse. A intuição e a conceptualização influem na posse a partir do nexo de causalidade e concretude em que ela se envolve.

A referência ao social pode ser feita através do fato social, da socialização e da função social.

A publicização da posse revela sua importância por concretizar o uso e o gozo das coisas pelas pessoas, para satisfação de suas necessidades vitais. A hermenêutica desses novos tempos deverá pautar-se em esparzir maior foco de luz sobre os fatos, desvencilhando-os de colisões com interpretações anteriores, principalmente quando essas derivem de simples hipóteses, sem base em fontes reais e, sobretudo, contemporâneas.

Wieacker observou que as formas sociais mais recentes, aliadas a novas fundamentações e às necessidades e interesses, quer dos indivíduos, quer da sociedade ou das comunidades, plasmam novos rumos para o direito - que passam a ser explicados como produto da vida social. (WIEACKER, 1967, p. 14)

A interpretação sofre os impactos dos contributos que acabam por influenciar uma nova maneira de ver o direito sob o aspecto das novas realidades.

As novas visões são impulsionadas pela opinio communis dos operadores do direito, de preferência aqueles afinados com a forma e, sobretudo, o espírito da Constituição e suas promanações de supralegalidade.

E não se nega a variabilidade das interpretações geminadas pelas polêmicas visões dos juristas incrementadas pela discussão das hipóteses jurídicas, na argumentação e na interpretação. E essas visões ou são tradicionais, revestindo-se de ortodoxias, ou são heterodoxas, incorporando a realidade, a verdadeira noção da função social, contemplando o novo.

Bem por isso é que Barassi recomendava, de longa data: "L'interprete deve indagare il concetto sostanziale dela norma (interprétazione lógica): questo é lo scopo vero dell' interpretazione." (BARASSI, 1914, p. 32.).

Henri de Page também recomendava: En dégager le sens, en determinant la portée et par voie de consequence, la mesure dans laquelle elle sera aplicabe. (De PAGE, 1948, p. 208)

Uma interpretação impõe-se, pois, no diapasão mesmo do dilema da vida. O gênero humano está enfrentando revoluções sem precedentes. Todas as narrativas antigas estão ruindo e são restritas as narrativas novas para substitui-las. No direito, os dogmas ruíram ou estão ruindo um a um. ${ }^{3}$

\footnotetext{
2 A dogmática moderna avaliza o entendimento de que as normas em geral e as normas constitucionais em particular, enquadram-se em duas grandes categorias diversas: os princípios e as regras. As regras contêm relato mais objetivo, incidindo, restritamente as situações especificas as quais dirigem. Já os princípios têm maior teor de abstração e única finalidade destacada no sistema (Luis Roberto Barroso - Interpretação e aplicação da Constituição - 2010, p. 329.). E o mesmo Ministro Barroso especifica os papeis desempenhados pelos princípios: a) condensar valores; b) dar unidade ao sistema; c) condicionar a atividade do interprete. Os princípios galgaram o status da norma jurídica. "Superando a crença de que teriam uma dimensão puramente axiológica, ética, sem eficácia jurídica imediata”

${ }^{3}$ Admite-se a mudança do caráter da posse (cc, art. 1198, parágrafo único; admite-se a execução sem título, derruindo a parêmia nulla executio sine titulo; admite-se a relativização da coisa julgada, desprestigiando a parêmia res indicata pro veritatene habetur; em caso de cancelamento do titulus de ius in re a posteriori o art. 1242, parágrafo único, presentes as exigências que estabelece, garante a usucapião; o art. 1255, parágrafo único, em sendo de boa-fé a acessão, mediante indenização o possuidor adquire a propriedade...
} 
Avaliando um panorama como este, não se justifica a transcendência da propriedade sobre a posse, como insistem os partidários do positivismo e da ortodoxia.

A propriedade, pelo menos explicitamente, está inserida entre os direitos e garantias individuais (art. $5^{\circ}$, caput $-\mathrm{CF}$ ), nos incisos XXII e XXIII do mesmo art $5^{\circ}$, embora com ressalva de atendimento à sua função social (art. $5^{\circ}$, inciso XXIII); e enquanto o inciso II, do artigo 170 contemple os princípios de acesso à propriedade privada, imanentemente exsurge o vínculo à função social (art. 170, III).

No entanto, a posse, enquanto respeita a efetiva e concreta utilização dos bens e não a sua titularidade provoca uma captio diminutio na situação proprietária, especialmente quando o possuidor reúne os requisitos da usucapião, que podem e devem ser arguidos em defesa pelo possuidor contra o proprietário ou titular dos iura in re aliena (Súmula 237-STF) e, amplamente, quando o possuidor tenha feito benfeitorias necessárias e úteis, as quais assistemlhe o ius retentionis.

Mesmo assim, a desmedida importância que o sistema atribui à propriedade pode ser assim resumida, muito embora com reparos essenciais no que concerne à posse:

$1^{\circ}$ ) garantias dadas à propriedade;

$2^{\circ}$ ) sua inserção entre os direitos e garantias fundamentais (art. $5^{\circ}$, caput, $\mathrm{CF}$ );

$3^{\circ}$ ) está elencada ao lado dos direitos à vida, à liberdade, à igualdade, à segurança (art. $5^{\circ}$, caput, $\mathrm{CF}$;

$4^{\circ}$ ) é garantida monossilabicamente no inciso XXII, art. $5^{\circ}, \mathrm{CF}$ : é garantido o direito de propriedade;

$\left.5^{\circ}\right)$ no inciso XXIII, art. $5^{\circ}, \mathrm{CF}$ : a propriedade atenderá a sua função social;

$\left.6^{\circ}\right)$ o Prof. Cesar Fiuza inclui a coletividade como co-partícipe do direito de propriedade, admitindo existir na propriedade um caráter dinâmico, consistente em relações que se movimentam e se transformam no tempo e no espaço (a posse);

$7^{\circ}$ ) a propriedade significa, tradicionalmente, um bem corpóreo, e econômico, com expressão patrimonial.

No entanto, a posse subverte essas concepções, haja vista o enunciado da Súmula $\mathrm{n}^{\circ}$ 193 STJ: O direito de uso de linha telefônica pode ser adquirido por usucapião. E a usucapião em toda sua concepção (constitucional, civilística e na legislação extravagante) permite a aquisição da propriedade, através da posse qualificada, não sendo a recíproca verdadeira.

Desse modo, nem a constatação milenar de a propriedade revestir-se de uma ideologia capitalista, conquistando o apogeu do direito privado, tem-se mostrado convincente na mantença dessa hegemonia da situação proprietária, edificada em base individualista, sob escudo de absolutismo e exclusividade. $\mathrm{O}$ açambarcamento do uso e gozo concreto e efetivo da posse abre um subdiscurso que descamba para o caráter ideológico, que, para Marilena Chauí, consiste no ocultamento da realidade. (CHAUI, 2004, p. 23)

A posse recebe um reforço adicional quando é utilizada para fins de moradia (possessio pro morare), para o trato da terra ou, ainda, quando se posta a motivar investimento de interesse social ou econômico ou, ainda, alternativamente, em caso de aquisição a non domino, a título oneroso, oportunizando a consumação da usucapião, mesmo se, a posteriori, for o título aquisitivo cancelado.

Esta hipótese resolveu o bimilenar, aflitivo e angustiante, problema da aquisição $a$ non domino (art. 1224, parágrafo único, CC). Et pour cause dessa vasta serventia da posse, começou-se a falar em repersonalização do campo privado, em geral, e da posse, em especial, órbita possessória na qual o individuo patrimonialista cede lugar à pessoa humana, preocupada com a sua realização (ser) e não com o enriquecimento a qualquer custo (ter). 
Para isso, a constituição constitucionalizou as normas civis, editando-as autoaplicáveis e elegeu princípios-base que servem a todo ordenamento infraconstitucional, os quais exigem uma reinterpretação hermenêutico-sistemática centrada na pessoa humana e não no individuo patrimonialista.

Estamos, assim, frente a uma nova realidade, exigindo que o intérprete se comprometa com a realidade social, abandonando de vez a tradição dogmático-positiva.

E tanto mais se impõe esse proposito que, decorridos 33 anos da promulgação da Constituição, o que se tem de concreto para a resolução do acesso à terra rural e à urbana? A interpretação não constitui valioso e eficaz meio de contemporanizar as incisivas mutações sociais? E até que ponto pode-se admitir o próprio positivismo constitucional?

A Constituição não pode constituir um simulacro e representar um empecilho institucional à efetivação do poder jurígeno no próprio interesse em prol dos sujeitos de direito: os cidadãos, o povo.

A universalidade é característica do Estado: para que ele seja democrático, imprescindível seja ele universal. O poder emana do povo e não do próprio Estado e de suas instituições. Essa formulação jurídica só terá validade se resultar de um processo político de inclusão e reconhecimento transformadores de súditos em cidadãos (MOREIRA, 2017, p. 114).

As transformações ocorridas no ambiente cultural do século XX provocaram a reviravolta hermenêutica de Martin Heidegger, de Hans Georg Gadamer, de Jurgen Habermas.

Essas transformações alteram o conceito de sujeito e a constituição de uma liberdade comunicativa assecuratória da existência de um processo constituinte permanente.

Cada contexto histórico exige reavaliação da vontade democrática dos cidadãos. Só assim, ao mesmo tempo que se mantém a vontade democrática dos cidadãos, que deve ser institucionalizada, evitar-se-ão decisões arbitrárias ou restritivas de direito (MOREIRA, 2017, p. 57).

$\mathrm{O}$ adjetivo social entremostra vinculação ao interesse coletivo e não no interesse do dominus - o que não significa que não possa haver harmonização entre um e outro (FACHINI NETO, 2009, p. 112).

A expressão e valoração desse social envolve a todos, inclusive o Estado. É que a função social se destina à utilização adequada do bem para a satisfação de necessidades, as necessidades limitam o conteúdo do direito.

A modificabilidade das instituições recebe uma ênfase quando se reveste de instrumento de proteção da personalidade humana, sua dignidade, seu bem-estar.

As drásticas transformações ocorridas no transcurso do século $\mathrm{XX}$ impactaram marcantemente o Direito, período em que ocorreu a passagem de uma época de segurança para uma época de incertezas. Tais mudanças paradigmáticas reduziram a importância desmedida do positivismo (que reduzia o direito à lei com a preocupação na mera proteção na autonomia individual, de caráter patrimonial), passando à preocupação e até imposição de uma proteção integral da pessoa humana, através da tutela de sua dignidade.

Há quem admita que os direitos do não-proprietário instabilizem as bases clássicas dos sujeitos ativo e passivo dos direitos reais, sustentando (CORTIANI JUNTER, 2002, p. 153154):

O não-proprietário não é mais apenas o sujeito passivo universal, titular de um dever genérico de abstenção, mas se insere em uma situação jurídica subjetiva complexa. Tem direito de exigir de quem proprietário o cumprimento da função social da propriedade, e tem direito a que lhe sejam dadas condições materiais de aceder à propriedade. $O$ discurso proprietário deve abranger $o$ acesso aos bens.

Mas que se voltem os olhos para o positivismo constitucional, os preceitos dos art. $182, \S 2^{\circ}$, e do 186 exigem o efetivo uso da coisa e seu exercício fático, eis a POSSE. Assim, 
mesmo que o proprietário seja simultaneamente possuidor, a FUNÇÃO será desempenhada através da POSSE, e somente dela. A atividade sobrepõe-se à titularidade.

Nelson Rosenvald e Cristiano Farias veem na concepção autônoma da posse a sua independência, consubstanciado a sua função social e sua distinção da situação proprietária que reside na titularidade, que deve ceder ante a realidade (ROSENVALD e FARIAS, 2006, p. 66$67)$.

A funcionalidade da posse irradia-se pelas modalidades constitucionais da usucapião (art. 183 e 191) e infraconstitucionais: art. $9^{\circ}$ ao 14 do Estatuto da Cidade; art. 1239 e $1240-$ CC; parágrafos únicos dos arts. 1238 e 1242 - CC; na concessão de uso especial para fins de moradia (art. 183, $\S 1^{\circ}$, CF e art. 1225, inciso XI - CC); na Lei n ${ }^{\circ} 6969 / 1981$; no estatuto da terra e já vinha de disposições constitucionais anteriores: Constituições de 1934 (art. 125); de 1937 (art. 148); de 1946 (art. 156, §3º ). É vastíssima essa demonstração de funcionalidade da posse.

Então surge a proibição da aquisição da posse de imóveis públicos e a consumação da usucapião.

Os preceitos que desautorizam a posse e sua prestabilidade à consumação da usucapião são de natureza constitucional e infraconstitucional: arts. $183, \S 3^{\circ}$ e 191, parágrafo único - CF; Art. 102 - CC; Decreto n 22.785 de 31/05/1933; Decreto-Lei no 710, de 17/09/1938; DecretoLei $\mathrm{n}^{\circ}$ 9760, de 05/09/1946; Arts. 66 e 67 do CC/1916 e Súmula 340-STF (na ótica jurisprudencial).

A função social é estruturante ${ }^{4}$, integra a essência da posse, que está subordinada às necessidades e anseios da pessoa e não como condicionadora da estratificação social, como em voga, operante e imperante.

A posse não pode mais ser vista à luz da ótica positivista. Tradicionalmente, no sistema do código civil francês (1804) e nas grandes codificações ocorridas no século XIX (Código suíço, alemão, italiano...), a posse representava o poder sobre as coisas, organizado mediante a propriedade e os direitos reais, deixando uma zona sem delimitações e poderes, os quais se legitimavam, quando existentes, daí chamados poderes de fato. Eis ai a posse autônoma, propriamente dita. E que gera uma certeza acerca do fato ou exercício de fato e uma grande dúvida acerca do direito. Assim, esse estado de coisas estabelece, segundo a ortodoxia, uma magnitude decorrente dos títulos de ius in re, prevalecendo, então o direito sobre os poderes de fato. Prevalecendo porque as decisões proferidas em juízo possessório não "prevalecem", porque não fazem coisa julgada a respeito da propriedade e dos iura in re aliena. Vencido no juízo possessório, o proprietário tem ao seu dispor o juízo petitório, no qual demandará a declaração de seu status proprietatis, onde será vencido apenas em casos como o de benfeitorias úteis e necessárias feitas pelo possuidor ou em caso de consumação da usucapião que poderá ser arguida em defesa triplicimente: no caso da Súmula 237 - STF; no caso do art. $7^{\circ}$ da Lei ${ }^{\circ}$ 6969, de 10/12/1981; e no caso do art. $9^{\circ}$ e 10 da Lei no 10.257, de 10/07/2001.

Mas o panorama, sob a ótica da densidade social contida na estrutura possessória, através da socialização, é totalmente diferente. A socialização é um processo e uma dialética que se nutre de uma realidade social decorrente de supostos fáticos, os quais, em existindo, conclamam consequências jurídicas de direitos subjetivos, faculdades e deveres.

Quando o proprietário ou os titulares de direitos reais invocam a existência do titulus de ius in re ou iura in re aliena, respectivamente, eles se habilitam a propor a ação reivindicatória, numa verdadeira soberania privada, sacralizadora. Daí surge uma prestação jurisdicional exclusivamente declarativa, restabelecedora da situação alterada na mudança da posse. Daí

\footnotetext{
${ }^{4} \mathrm{O}$ conceito de estrutura é utilizado aqui com a significação para além do seu sentido como instituição, quando tem variado sentido. Aqui concerne o fator organizador e diretivo de uma realidade considerada em função da totalidade.
} 
nascem aforismas, os mais diversos, decorrentes de doutrinas de vários colores: reivindica quem é dono contra quem mal possui; a reivindicatória é a ação do proprietário não possuidor contra o possuidor não proprietário...

A defesa do possuidor resume-se ou à invocação da usucapião arguída em defesa ou, com menos intensidade, diante de comprovada posse de boa-fé, a retenção da coisa pelo possuidor até que se lhe paguem o valor das benfeitorias necessárias e úteis, podendo destacar as voluptuárias, em não havendo dano à coisa. Fora dessas exceções, só existem incertezas do possuidor frente ao reivindicante-proprietário ou do titular dos iura in re aliena. Excepcionese, no entanto, que na reivindicatória a posse do legitimado passivo há de ser, necessariamente, injusta. E no plano heterodoxo, a posse dos legitimados ativos deverá revelar o cumprimento da função social, sob pena de não lograr êxito no pleito.

Hernandez Gil, examinando a posição da posse, acrescentou que los juristas, acostumbrados a la tarea de la racionalización, no encuentran el encaje adecuado para esta pieza extraña y sutil, esencial y ziquezaqueante (GIL, 1969, p. 123).

Vista assim, a posse não passaria de uma estrutura não transformada de todo em instituição jurídica. Mas esse status não pode ser concebido pela simples e singela razão de sua efetividade jurídica ter como suporte a realidade social. Demonstração disso é que somente através da posse pode-se ter o uso e gozo efetivos e concretos da coisa. Os aficcionados na superioridade ontológica da propriedade e dos iura in re aliena, centrados no positivismo exacerbado, ainda que anacrônico, tendem a converter o instituto da posse em puro mecanismo técnico desprovido de vitalidade. Daí a visão da posse estreitada no simples exercício de fato dos poderes da propriedade e dos iura in re aliena. Simples repetição do que se contém no art. 1228 e 1225 - CC. Essa, aliás, fruto da visão trazida e repetida nos livros de direito civil, com o apoio de um aparato doutrinário-jurisprudencial carregado de tradição, propício a sutilezas intelectuais, na contramão das palavras de Cogliolo: $O$ trabalho lógico do jurista exige-lhe a visão a respeito das necessidades e força de pensamento, relação econômica e ilação lógica, instrumentos de que deve servir-se o jurista perfeito. E esse viés hermenêutico não deve ser preterido.

Sabe-se que os embaraços conceituais sobre se a posse é um direito real ou um direito pessoal contribuem para obstaculizar a colocação da posse como instituto estruturado e integrante da função do Estado Social, mantenedor de um programa de igualdade na distribuição dos recursos coletivos.

Não é novidade: nessa discussão entre personalistas e realistas, o positivismo normativo impera, absoluto. Sob a ótica processual, a ação real distingue-se da pessoal, "porque aquela se encontra ligada a um direito real e esta é conexa a um direito obrigacional" (MARQUES, 1977, p. 173).

Humberto Teodoro Júnior, após discorrer longamente sobre se as ações possessórias são ações reais ou pessoais, arrimando-se nas lições de Caio Mário da Silva Pereira, Orlando Gomes, Celso Agrícola Barbi (defensores da ideia de tratar-se de ações reais), informa, inobstante, o posicionamento do STJ que as entende ações pessoais, mesmo tendo por objeto bens imóveis THEODORO JÚNIOR, 2016, p. 138).

O CPC/1973 considerava as ações possessórias ações reais (art. 95 e 102). E o CPC/2015 (art. 43 e 47), além de considerá-las ações reais, reserva ao juízo do foro da situação da coisa (locci rei sitae) competência absoluta.

Embora criada dificuldade de toda ordem quanto a posse, vê-se que o desprestígio a que a submetem não tem sentido.

E se obstáculos é que não faltam quando o tema é a posse, as dificuldades prolificam quando se fala em usucapião de imóveis públicos.

A função social da posse suscetibiliza a resolução dessas discussões porque, autonomizando-se a posse, desligando-a da propriedade e dos direitos reais sobre coisas alheias, 
a sua tutela impor-se-á fora dessas limitações tradicionalmente antepostas, porque dar-se-á por ela mesma, mesmo frente a outros desperdícios inconsequentes, como a supressão formal das ações de nunciação de obra nova e de embargos de terceiro, que foram banidas do rol das ações possessórias, as quais, hoje, resumem-se às ações de manutenção de posse, reintegração de posse e de interdito proibitório. No entanto, a propriedade é, por concepção legal, um direito e os direitos são abstratos. A posse é que instrumentaliza o bem-estar, a cidadania, a dignidade da pessoa, que são princípios fundamentais do Estado Democrático de Direito. Por isso mesmo a posse suscetibiliza, concretamente, a função social. É a função social que propicia a utilização dos bens.

Como observou Ana Rita Vieira Albuquerque, isso se faz

através do descompasso metodológico entre a práxis judicial e o que dispõe o estatuto privatístico acerca da posse, ou seja, um instituto concebido independentemente da propriedade, capaz por si mesmo de responder as contingências sociais (ALBUQUERQUE, 2002, p. XIII).

A função social da posse deriva da quebra da rígida separação entre o público e o privado, que constitui o direito privado no passado e da própria mudança de parâmetros do individualismo e da patrimonialização para a funcionalização e para a projeção constitucional.

A dicotomia entre direito público e direito privado, pois, é coisa do passado, pois ambos integram o mesmo ordenamento jurídico uno, indivisível, sob inspiração constitucional.

Percebe-se que o Estado se demite ou é demitido de suas funções, mediante a fragilização de sua capacidade de atuar efetivamente, sobretudo em assegurar a qualquer pessoa condições mínimas para uma vida condigna através de um mínimo existencial, núcleo dos direitos sociais, como notou Sarlet (2009, p. 73).

O princípio constitucional da posse, ao contrário, tem como consequência direta, a garantia da efetividade dos princípios estruturantes do Estado Democrático de Direito, dentre os quais o princípio da dignidade humana. À luz de tais princípios, há maior efetividade às normas infraconstitucionais acerca da posse. E dessa forma, a concepção originária da posse sofre alterações para adaptar-se à realidade social. Afastando-se do fetiche da propriedade, a posse passará a ser informada pela utilização do solo, por seu aproveitamento útil, para fins de moradia e beneficiamento da terra, como fator de diminuição das desigualdades sociais.

No que concerne a usucapibilidade dos bens públicos, revela-se contraditória a ideia da sua inalienabilidade. Há a admissibilidade das "legitimações" das terras devolutas, desde que haja pagamentos ao erário. Quer dizer, se pagar, resulta ineficacizada a inalienabilidade. Não será esta uma visão marcantemente patrimonialista, na contramão da tendência de valorizar o ser humano: ser no lugar do ter?

A análise dessa quaestio revela a relevância dos problemas concretos relativos à posse suscitando os conflitos de interesse entre o proprietário que não exerce o direito de propriedade, segundo a função social, e o possuidor cuja posse exerça função social. Mesmo quando o proprietário seja o Estado e, pois, quanto aos imóveis públicos.

A propriedade pública é destinada aos cidadãos, porque ela somente se justifica se e quando postar-se à efetiva utilização. Constitui utopia sustentar que a propriedade pública traz em si, imanentemente, o interesse social. Isso não convence porque não há efetividade e concretude. Afinal, o Estado nos moldes em que o conhecemos, não consegue realizar a contento nenhuma de suas atribuições.

O descumprimento dos deveres do Estado quanto a função social não provocaria a desafetação forçada pela realidade?

\section{A NOVA REALIDADE NA CONSTITUIÇÃO DA REPÚBLICA FEDERATIVA DO BRASIL DE 1988}


A Constituição de 1988 rompeu com o absolutismo da propriedade, adequando a propriedade e a posse a uma nova visão: a do estado social, em que mais pessoas possam ter acesso à terra e, ao desenvolvimento sócio-econômico, especialmente aos benefícios dele advindos. Como, então, ela própria cria obstáculos a esse acesso?

A função social da posse constitui tema umbilicalmente ligado à dignidade da pessoa humana, porque instrumentaliza e efetiva o acesso à moradia e à ocupação das terras rurais. Ela constitui requisito primordial à consumação de qualquer modalidade de usucapião, mostrandose necessária e imprescindível à usucapião de imóveis públicos, mediante a desdogmatização que bens públicos não sejam suscetíveis de usucapião e a partir da superação da ideia de hierarquia e ruptura sistemática entre o direito público e o direito privado, pois ambos estão vinculados aos princípios constitucionais.

O direito público vem sofrendo considerável privatização, na medida em que obriga o Estado a ser o primeiro a dar o exemplo tanto na órbita jurídica como na social e econômica, sempre tendo como finalidade o bem comum e o interesse social.

Afinal, a atuação estatal na esfera privada objetiva a integração dos excluídos do tecido social.

Não se pode negar o grande alcance social da usucapião, através da qual o possuidor do imóvel chega a adquirir-lhe o domínio. O tempo tem uma forte significação jurídica. Particular caso de prescrição, o tempo legitima situação que, na sua origem, se encontrava fora da relação jurídica. Ao tempo se unem a posse e requisitos outros segundo as suas diversas modalidades. Mas a posse é o elemento mater pela qual há, simultaneamente, a perda do direito do antigo proprietário e a aquisição de um novo direito por parte do usucapiente.

A posse e a usucapião dos bens dominicais, admitidas sem relutâncias, decorreram da independência e autonomia da posse, consubstanciadoras da sua função social, tão dinâmica quanto a posse proprietária, que reside na titularidade.

Constitucionalmente, os arts. $5^{\circ}$, inciso XXIII e 170, inciso III, asseguram a função social e uma existência digna conforme os ditames de justiça social. O bem-estar, o desenvolvimento, a cidadania, a dignidade da pessoa são princípios fundamentais do Estado Democrático de Direito. É dever do Estado garanti-los, preservá-los, estimulá-los executá-los.

A própria Constituição estabelece quando e como a propriedade cumpre sua função social, embora metonimicamente é da posse que tratam seus arts. $182, \S 2^{\circ}$ e 186 , porque de suas verba legis se conclui que só através da posse obtém-se sua concretude.

A posse das terras rural e urbana públicas estariam aguardando uma Emenda Constitucional para prestar-se à sua vocação natural de colocarem-se ao alcance dos cidadãos? Necessitar-se-á de uma promulgação futura (de lege ferenda) ou já foram e estão implementadas no texto constitucional? Não é razoável responder que a Constituição instituiu tais garantias, seja ao reconhecer a dignidade da pessoa humana e a cidadania como fundamento do Estado Democrático de Direito; quer reconhecendo os direitos fundamentais e sociais (arts. $5^{\circ}$ e $6^{\circ}$ ) e, ainda, decorrentes da supralegalidade irradiada do seu Preâmbulo?

Se não se implementa a função social para possibilitar o uso, o gozo, a disposição e a aquisição per usucapionem de ius in re por obstáculos ditos de imprescritibilidade, de inalienabilidade, a Constituição não representaria o mesmo e criticável positivismo jurídico?

Ora, a função social da posse significa poder dar ao imóvel que se constitui em seu objeto o destino funcional efetivo, concreto, vinculando-o a certo objetivo. As limitações, como imprescritíveis, inalienáveis, limites negativos que são, restringem a sua utilização, sob a justificativa vetusta e inadequada, socialmente, de que os bens públicos se destinam ao bemestar do povo, estando em prol do seu interesse. Nada mais irreal, abstrato e genérico. Constitui ressalva para blindar tais bens, impondo-lhes a imprescritibilidade.

As normas que estabelecem a função social da posse disciplinam um fim a ser alcançado. Bem por isso, as normas proibitivas da consumação da usucapião de imóveis 
públicos retiram o mais importante meio de realização da função social. E com isso a configuração de uma antinomia teleológica que precisa ser contornada.

Maria Helena Diniz sustenta que os arts. 5', XXIII, 170, III, 182 e 186 tipificam princípios, enquanto os arts. $183, \S 3^{\circ}$ e o 191 , parágrafo única adequam regras, de sorte que essa antinomia pode converter-se em normativas (DINIZ, 2017).

Já foi estabelecida a distinção entre os princípios e as regras, mas não é perdulário acolher a lição de Canotilho, para quem "os princípios são normas com um grau de abstração relativamente elevada enquanto as regras possuem uma abstração relativamente reduzida" (CANOTILHO, 2002, p. 1086-1087).

Jorge Miranda vê nos princípios critérios de interpretação e integração, pois são eles que dão coerência geral ao sistema (MIRANDA, 1991, p. 226-227).

E Luís Roberto Barroso escreve: "O ponto de partida do intérprete há de ser sempre os princípios constitucionais, que são o conjunto de normas que espelham a ideologia da constituição, seus postulados básicos e seus fins" (BARROSO, 2002, p. 149-150).

Silvio Luís Rocha, mais específico arremata que os princípios, enquanto princípiogarantia (art. $5^{\circ}$, XXIII - CR/88) e princípio político conformadores da organização econômicosocial do Estado (arts. 170, III, 182, $\$ 2^{\circ}$ e 186), fornecem diretrizes e interpretações das outras normas constitucionais. As regras proibitivas da usucapião de bens públicos (arts. $183, \S 3^{\circ} \mathrm{e}$ 191, parágrafo único da $\mathrm{CF}$ ) devem ser interpretadas e compreendidas à luz do princípio da função social da propriedade pública (ROCHA, 2005, p. 151).

$\mathrm{O}$ direito à moradia e ao trato da terra constituem um ponto central do direito humano. Betânia Alfonsin os vê resguardados na segurança da posse, como se colhe de suas próprias palavras: "A segurança da posse, por se tratar de elemento central do direito humano à moradia, deve ser assegurada a todos, com igualdade e sem discriminação, abrangendo todos os indivíduos e famílias independentemente de idade, status econômico, grupo ou outra afiliação e status." (ALFONSIN, 2004).

O acesso à propriedade imobiliária, pacificamente, dá-se pela usucapião. Eis a necessidade de superação do legalismo estrito e adoção de progressiva valoração do intérprete e aplicador do direito para dar resposta aos conflitos estabelecidos à sua evitabilidade, admitindo-se a usucapibilidade em geral.

Os bens públicos no regime do CC/1916 eram tríplices: a) de uso comum; b) de uso especial e; c) dominicais (art. 66). No CC/2002 (art. 98) estão definidos como público os bens do domínio nacional pertencentes às pessoas jurídicas de direito público interno.

A Constituição preceitua (art. 225) que os bens públicos são de uso comum do povo, id est, de fruição uti universi; de uso especial, quais os que possam ser objeto de permissão ou concessão de direito real aos administrados; e os bens dominicais, os quais a administração dispõe como simples proprietária.

De há muito, Pontes de Miranda já entendia que, à falta de regras jurídicas sobre os bens dominicais, incidia neles o regramento do direito privado (MIRANDA, 1983, p. 136).

Todos os bens públicos, segundo consenso doutrinário antigo, são tipificados como inalienáveis só podendo ser alienados após desafetação e obedecidos os requisitos da Lei $\mathrm{n}^{\circ}$ $8.666 / 1993$, arts. 17 a 19. O art. 100 do CC, entretanto, preceitua que os bens públicos de uso comum do povo e os de uso especial são inalienáveis, "enquanto conservaram a sua qualificação, na forma que a lei determina".

Mas é preciso atentar que esses condicionamentos, mesmo em se cuidando de bens de uso comum do povo e de bens de uso especial (art. 17, caput, da Lei $\mathrm{n}^{\circ}$ 8.666/1993), estão subordinados "à existência de interesse público devidamente justificado". Bem por isso, os critérios são os da economicidade e não os de socialidade e funcionalidade, hierarquicamente superiores àqueles. Juarez Freitas refere à transmutação de classe dos bens de uso comum e os de uso especial, quando operada a desafetação, "convertendo-os em dominicais, que, 
mediante avaliação prévia e, em regra, licitação, são efetivamente disponíveis" (FREITAS, 1994, p. 216). Mas, ainda assim, ressai a predominância do elemento econômico antepondo-se a funcionalidade social.

É preciso convir que a Lei Maior elegeu valores maiores os quais destinou à concretização de seus escopos. E sobre ter criado a "propriedade mínima", erigiu a moradia à categoria de direito fundamental, filiando-a à dignidade da pessoa humana e à cidadania.

No confronto entre um mero, genérico e abstrato interesse público e os valores maiores referidos, resulta induvidoso que estes sobrepujem aquele, principalmente porque aqueles, também, recebem a chancela de interesse público, que o estado tem o dever de assegurar e de resguardar.

\section{TERRAS DEVOLUTAS: USUCAPIBILIDADE}

No rol dos bens públicos da União (art. 20, inciso II, da Constituição) ou, por exclusão, dos estados (art.26, inciso IV) figuram expressamente as terras devolutas.

A doutrina ortodoxa sustenta inusucapibilidade das terras devolutas como, de resto, dos bens públicos em geral. Mas, heterodoxamente, cumpre examinar se deve conformar com aquele entendimento.

O exame é desafiador. Ao que se extrai do disposto no art. 188 da Constituição, há visível distinção entre terras públicas e terras devolutas, evidenciando, gramaticalmente, pela conjunção aditiva "e": terras públicas e "devolutas"

O Prof. Silvio Rodrigues, depois de deter-se nas disposições do art. 188 da Constituição, observou que o constituinte diferençou e distinguiu "as terras públicas das devolutas". E acrescentou que "criou um novo gênero de bens públicos dominiais, os das terras devolutas". (RODRIGUES, 2002, p. 148).

A hermenêutica jurídica releva a voluntas legis não a voluntas legislatoris (FREITAS, abril/94, fls. 217). Assim, mesmo que o constituinte não tenha desejado, fato é que, inegavelmente, fez a distinção.

É razoável indagar, então: teria o constituinte classificado as terras devolutas como não públicas? As terras devolutas integrariam a classe de bens dominicais?

Pontes de Miranda (1983, p. 135) inspirou Tupinambá Nascimento (1989, p. 142-150), porque este, seguindo lição daquele, ao distinguir bens públicos de bens particulares, sustenta que os bens dominicais não seriam bens públicos stricto sensu, uma vez que supostamente pertencentes ao Poder público, a título privado antiga jurisprudência reconhecida, peremptoriamente, a usucapibilidade das terras devolutas. E apenas excepcionalmente negava essa possibilidade. Colhe-se em Bussada (1984, p. 349 e ss.):

01566 - TERRAS DEVOLUTAS. ÁREA NÃO TRANSCRITA EM NOME DE PARTICULAR. Desnecessidade. Posse devidamente comprovada. Sentença confirmada.

Segundo jurisprudência reiterada deste Tribunal, o fato de não se encontrar transcrita, em nome de particular, certa e determinada área, não gera a presunção de ser a mesma de propriedade do Estado. - (1 ${ }^{\mathrm{a}} \mathrm{CC}$ do TJSP, apel. no 14.908 , v. um. E, 20-12-1979, rel. Des NAPOLEÃO AMARANTE, Jusrisp. Catarinense-28/288)

1567 - TERRAS DEVOLUTAS - Usucapião. Falta de prova de caráter devoluto. A alegação de que se trata de terras devolutas deve ser provada pela Fazenda do Estado que contesta a ação de usucapião. - ( $1^{\text {a }}$ CC do TJSP, apel. $n^{\circ} 282.333$ (reexame), v. um. em 26-6-1979, rel. Des. VIEIRA DE MORAES, RT-541/131). 
1568 - TERRAS DEVOLUTAS - Prova - Gleba de terra - Prova de ser terra devoluta não oferecida pelo Estado - Posse por longos anos - Falecimento do possuidor - Transmissão aos herdeiros - Ação procedente - Recurso não provido.

Ao Estado, que contesta ação de usucapião, cabe oferecer prova de que se trata de terra devoluta, se apresentar essa alegação. Falecendo o possuidor, a posse transmitese com os mesmos caracteres aos seus herdeiros. - ( $2^{\text {a }}$ CC do TJSP, apel. $\mathrm{n}^{\mathbf{o}} 273.616$ (reexame), v. um. em 20-3-1979, rel. desig. Des. TPLEDO CÉSAR, RT-529/68).

1570 - TERRAS DEVOLUTAS - Propriedade sem registro.

É inaceitável a tese, hoje superada, de que se a propriedade não estiver registrada presume-se devoluta, e consequentemente do Estado. Inépcia da inicial repelida em caso de inexistência de registro anterior. Prosseguimento do feito até final. - $\left(2^{\mathrm{a}} \mathrm{CC}\right.$ do TJSC, apel. $\mathrm{n}^{\circ}$ 12.930, v. um. em 09-3-1978, rel. Des. GERALDO SALLES, Jurisprudência Catarinense-21/100.)

1571 - TERRAS DEVOLUTAS - Prova.

Usucapião. Alegação de serem devolutas as terras, visto não se haver comprovado, mediante a exibição de transcrição, a entrada do imóvel no domínio particular. Admissibilidade de outros meios de prova para comprovação de que não são devolutas as terras. Matéria que envolve exame de prova. - ( $2^{\mathrm{a}} \mathrm{T}$ do STF, RE $\mathrm{n}^{\circ}$ 84.063-SP, v. un. Em 08-3-1977, rel min. LEITÃO DE ABREU, RTJ-81/191)

1572 - TERRAS DEVOLUTAS - Gleba de terra não transcrita no Registro de Imóveis.

O fato de uma gleba de terra não estar transcrita no Registro de Imóveis não significa

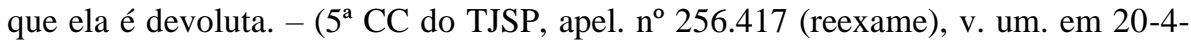
1977, rel. Des. SYDNEY SANCHES, RT-520/141.)

1573 - TERRAS DEVOLUTAS - Gleba de terra não transcrita no Registro de Imóveis. $\mathrm{O}$ fato de um terreno não se achar transcrito em nome particular não gera a presunção de ser o mesmo de propriedade pública, pois que a entidade pública está obrigada a provar o seu domínio sobre as terras que entender sejam devolutas. $-\left(2^{\mathrm{a}}\right.$ CC do TJSC, apel. n.c 12.819, v. un. e, 10-11-1977, rel. Des. OSNY CAETANO, RT520/273.)

1574 - TERRAS DEVOLUTAS - Ação de usucapião. Alegação de tratar-se de terras devolutas. Necessidade de prova. Desprovimento do recurso. Transcrição. Pelo fato de não achar-se transcrita, a área de terras não pode ser considerada como propriedade do Estado, pois a este cabe a obrigação de provar o seu domínio sobre terras que pretende sejam devolutas. - (2 $2^{\mathrm{a}}$ CC do TJSC, ag. De inst. $\mathrm{N}^{\mathrm{o}} 1.029$, v. un. e, 10-111977, rel. Des. NELSON KONRAD, jurisp. Catarienense, 19/20, p.308)

1575 - TERRAS DEVOLUTAS - Domínio do Estado. Prova. Ação procedente. Sentença confirmada. $\mathrm{O}$ fato de um terreno não se achar transcrito em nome particular, não gera a presunção de ser o mesmo de propriedade pública, pois que a entidade pública está obrigada a provas o seu domínio sobre as terras que entender sejam devolutas (Jurisprudência Catarinense, 1973, vol II, pág. 116).

1576 - TERRAS DEVOLUTAS - Alegação pelo Estado - Ônus da prova a seu cargo - Ação procedente. Contestando e afirmando o Estado tratar-se o imóvel objeto de ação de usucapião de terras devolutas, a ele compete o ônus da prova. - ( $3^{\mathrm{a}} \mathrm{CC}$ do TJMG, apel. $\mathrm{n}^{\circ}$ 47.021, v. un. Em 17-8-1979, rel Des. MONTEIRO DE BARROSO, RT-531/191.)

1577- TERRAS DEVOLUTAS - O fato de um terreno não se achar transcrito em nome particular, não gera a presunção de ser o mesmo de propriedade pública, pois que a entidade pública está obrigada a provar o seu domínio sobre as terras que entender sejam devolutas. - (2 ${ }^{\circ}$ CC do TJSC, apel. $n^{\circ}$ 14.027, v. un. Em 19-4-1979, rel. Des. OSNY CAETANO, Jurisp. Catarinense-23/24 pág.206) 
1580 - Terras devolutas. Usucapião. Não se presumem devolutos os imóveis não transcritos, precipuamente, na fase anterior ao Código Civil. A condição de devolutos deve ser provada. Reconhecimento do usucapião. - (6 $6^{\text {a }}$ CC do TJRJ, apel. $n^{\circ} 82.444$, v. um. Em 17-7-1973, rel. Des. DÉCIO PIO BORGES DE CASTRO, Rev. de Jurisp. De TJRJ - 35/129).

1581 - Terras devolutas. Usucapião extraordinário - Não se considera terra devoluta o terreno murado, com prédio edificado, em logradouro público, com numeração própria, sob a posse tranquila do particular, há longos anos, com impostos pagos. - (2 ${ }^{\mathrm{a}}$ CC do TJRJ, apel. n88.209, v. un. Em 15-5-1974, rel. Des. EUCLIDES FELIX DE SOUZA, Rev. de Jurisp. Do TJRJ-34/174).

1586 - TERRAS DEVOLUTAS - Domínio particular.

Não são devolutas as terras integradas no domínio particular há mais de vinte anos ( $2^{\text {a }}$ CC do TJPR, ap. 454/62, ac 40.443, RT-335/333.)

1586 - TERRAS DEVOLUTAS - Domínio particular.

Terras integradas no domínio particular, há mais de vinte anos, não podem ser consideradas devolutas. - ( ${ }^{\mathrm{a}}$ CC do TJPR, ap.216/61, ac.38.539, RT-326/608)

1588 - TERRAS DEVOLUTAS - Alegação pelo Estado. Falta de prova.

A alegação pelo Estado de serem as terras, objeto de ação, devolutas, não o exime de fazer prova plena daquela situação. - (TJPR, ap.215/60, ac. 34.848, RT-304/745.)

1595 - TERRENO DEVOLUTO - Ônus da prova. Usucapião. Alegação de Estado membro de que cabe ao usucapiente o ônus da prova de que a gleba em causa não é terra devoluta, não bastando, para comprová-lo, o depoimento de testemunhas e existência de indícios.

Inexiste em favor do Estado a presunção iuris tantum que ele pretende extrair do art. $3^{\circ}$ da Lei 601 , de 18 de setembro de 1850 . Esse texto legal definiu, por exclusão, as terras públicas que deveriam ser consideradas devolutas, o que é diferente de declarar que toda gleba que não seja particular é pública, havendo presunção iuris tantum de que as terras são públicas.

Cabia, pois, ao Estado o ônus da prova de que, no caso, se tratava de terreno devoluto. Recurso Extraordinário não conhecido - (2 $2^{\mathrm{a}} \mathrm{T}$ do STF, RE no 86.234, v. un. Em 1211-1976, rel. Min. MOREIRA ALVES, RTJ-83/575.) (BUSSADA,1984)

Os bens patrimoniais devolutos, ao lado dos bens dominicais, encontram fundamento no preceito do art. 188 da Constituição. E ganha vigor com a recepção tão tranquila quanto tácita do instituto da legislação da posse (de índole Constitucional - art. 164 - CF/1967), do instituto da regularização fundiária, dentre outros. $\mathrm{Na}$ legislação de posse, sua serventia é mesma a de transferência de domínio de terras públicas para dar-lhes "destinação compatível com o interesse público" (FREITAS, 1994, p. 219).

Bem se vê que uma interpretação desta natureza atende aquela recomendação valiosa de Emílio Betti (1955, p. 581), segundo a qual: "Il giurista deve conservar alle categorie che usa quel grado di elasticitá e di força dâmica che le renda nell loro storica peculiaritá".

Há também, a submissão dos bens públicos à função social, porque esta é, precedentemente, em razão mesma do fim público a que se destinam, estariam obrigados em razão de interpretação do texto constitucional a atender a função social inerente aos bens que integram o domínio privado.

Lopez y Lopez (1988, p. 85) reconhece que o exercício do direito de propriedade dos bens públicos, inclusive os bens patrimoniais, é o adequado atendimento dos fins públicos, que se supõem presentes: "Em la medida en que aquellos fines non resultam contradichos, cabe 
exigir de los entes públicos que acomodem la utilización de susbienes de domínio privado a los parâmetros de la función social".

E Sílvio Rocha $(2005$, p. 124) entende que os bens públicos: "Estão submetidos ao cumprimento de uma função social, pois servem de instrumento para a realização, pela administração pública, dos fins a que está obrigada."

Enfim, o fim público é mesmo a destinação dos bens públicos. Só que efetivos, concreto.

As terras devolutas, constituindo embora uma das espécies do gênero terras públicas, por isso elas integram a categoria de bens dominicais, precisamente pelo fato de não terem qualquer destinação pública - inobstante elas são disponíveis (DIPIETRO, 2013, p. 784)

A usucapião das terras devolutas é autorizada pelo art. 188 da Constituição que distinguiu as terras devolutas das terras públicas. É a lição de Bastos:

\begin{abstract}
As terras devolutas não estão vinculadas ao atingimento de um fim público. Permanecem como um estoque de terras ainda não transpassado aos particulares ou, tendo um dia estado em suas mãos, já tornaram à origem em razão do donatário ter caído em comisso. $\mathrm{O}$ fato é que estas terras são possuídas pelos Poderes Públicos à moda de um particular. Devem, portanto, estar sujeitas a usucapião, não colhidas, pois, pela expressão 'imóveis públicos' a que se refere o texto comentado. Esta distinção entre os bens públicos e as terras devolutas já era defendida por autores de grande tomo no nosso direito público. A matéria, contudo, em face do advento da atual Constituição, parece ter-se desapegado das areias movediças dos debates doutrinários para ingressar na arena segura da positivação jurídica. Assim é que o art. 188 da Lei Maior faz referência no mesmo preceito às terras públicas e às terras devolutas, deixando certo que acolheu a distinção esposada cientificamente. Se as terras devolutas fossem públicas, não haveria necessidade da sua referência. (BASTOS, 1990, p. 239-240)
\end{abstract}

A Constituição abraça, portanto, de forma desenganada a teoria segundo a qual as pessoas de direito público podem possuir terras à moda de um particular, isto é, sem estarem submetidos a regime de direito público decorrente da destinação a que está atrelada.

\title{
5 USUCAPIBILIDADE DOS IMÓVEIS DITOS DE USO COMUM DO POVO E DOS DE USO ESPECIAL
}

Não é perdulário repetir que o entendimento do descabimento da usucapião incidente sobre os bens públicos decorre do texto constitucional e dos infraconstitucionais diversos, irradiando-se pela jurisprudência cujo enunciado ${ }^{\circ} 340$ da Súmula do STF, embora antigo de mais de meio século, vêm constituindo numa barreira, à usucapibilidade dos imóveis públicos em geral.

Já vimos.

Escrevi alhures que as necessidades práticas, sob a pressão dos fatos, formam, constantemente, instituições jurídicas novas. Na contemporaneidade, o direito é um estado completo de transformações, geratriz de instituições jurídicas novas, continuamente elaboradas. (MIRANDA FILHO, 2011, p. 325)

Dir-se-ia que, hoje, a função social é uma das perspectivas da dogmática jurídica, tratando-se de verdadeiro princípio jurídico, como observara Comte (1890, p. 361), ainda no século XIX.

A concretização da autonomia, da independência, da funcionalidade e da inserção da posse como instrumento de realização dos direitos sociais e dos direitos fundamentais deverá ser construída interpretativamente, com criatividade e, assim

Implementar a máxima função social, como causa e como efeito, harmonizando seu exercício com aqueles valores, não só através do instituto da usucapião, senão também 
no caráter funcional que a posse desempenha prestando-se como meio jurídico e pacífico de acesso aos bens e de concretização do interesse social. (MIRANDA FILHO, 2011, p. 326)

A usucapião de imóveis públicos é instrumento de exercício de direito fundamental, decorrente de princípios gerais da Constituição dentre os quais a dignidade da pessoa humana e a função social da posse. Bem por isso, a usucapião objetiva a efetividade e concretude da função social da posse, possibilitando o acesso ao status proprietatis, possibilitando a moradia e o plantio, cultivo e exercitamento da agroindústria, para usar um linguajar contemporâneo.

Não pode haver contradição entre os objetivos explicitados no Preâmbulo da Constituição e seus preceitos positivados. Axiologicamente, os objetivos do Estado Democrático de Direito irmanam-se com os valores ínsitos na supralegalidade. Esses valores antepõem-se à formalidade, por constituírem valores supremos, como queria Bachof (2014, p. $63)$.

Em abono a esse entendimento, o prof. Ferreira Filho sustenta que contrapondo à lei e ao Direito "evidentemente a constituição alemã reconhece haver um direito não legislado, não escrito, quer substanciado em princípios suprapositivos, quer traduzido em costumes jurídicos." (FERREIRA FILHO, 2010, p. 110)

Também Canotilho (1998, p. 75), ao referir-se à limitação do Poder Constituinte, reclama a "observância de certos princípios suprapositivos", quer como "princípios supralegais, mas intra-jurídicos."

Ferreira Filho, visualizando o problema sob a ótica da abrangência da Constituição, revela que a tese da existência de normas suprapositivas traz como implicação a de que

A Lei Suprema "compreende", além de normas constantes do texto formal batizado de Constituição, Lei fundamental, ou equivalente, regras outras, não escritas, mas que a integram do ângulo material. Ou seja, a Constituição "material” é mais abrangente que a Constituição formal. (FERREIRA FILHO, 2010, p. 112)

Sob o ângulo de lege lata, a propriedade e a posse imobiliárias perderam seu foco como institutos individuais egoísticos. Sobre elas foram projetadas as luzes da função social e sua irradiação pela amplitude dos direitos fundamentais. Essas características, que são patentes, suprimem prerrogativas e faculdades de quem quer que seja (inclusive e principalmente do Estado). Eis um diagnóstico a que são opostas resistências de toda ordem. Mas tais princípios fundantes, apoiados em valores fundamentais põem em relevo a finalidade social, destino de todos os bens, especialmente os do Estado.

Por isso mesmo, Bobbio (2004, p. 53 e ss.) observou que interessa a perspectiva funcionalizada da propriedade (ao que acrescento, e sobretudo da posse), indagando: "para que serve o direito de propriedade" (e eu acrescento: para que serve a posse) e não mais "do que é feito o direito de propriedade".

Pietro Rescigno (1928, p. 209) destacou que o status proprietatis cria um vínculo com outros sujeitos em posição juridicamente relevantes, cuja proteção materializa os interesses de toda a coletividade.

Sob a ótica de iure condendo, com contributos de novas concepções que auxiliam o intérprete a buscar as mudanças exigidas pela realidade e contemporaneidade: qualquer que seja o enfoque, faz-se mister que na via ampla da interpretação o intérprete possa descobrir o sentido do direito "rumo à construção de um Estado de Direito sinônimo de Estado de Justiça." (DECICCO, 2017)

O processo teleológico ou sociológico busca a finalidade, a ratio do preceito normativo para, a partir dele, determinar o seu sentido.

$\mathrm{O}$ art. $5^{\circ}$ da LINDB determina que "o juiz atenderá aos fins sociais do direito e às exigências do bem comum".

Tércio Sampaio Ferraz Júnior (1988, p. 265-266), escoliando este dispositivo avalia que os termos 'fins sociais' e 'bem comum' são sínteses éticas da vida em comunidade, por 
pressuporem uma unidade de objetivos do comportamento humano. Os fins sociais são do direito, sendo necessário encontrar a finalidade do preceito normativo. $\mathrm{O}$ bem comum, a seu turno, postula uma exigência que se faz à própria sociedade, não se tratando de um fim do direito, mas da vida social.

Assim, não se nega, peremptoriamente, a existência de bens de uso comum do povo, como são as terras indispensáveis à defesa das fronteiras, das fortificações e das construções militares, das vias federais de comunicação, das áreas de preservação do meio-ambiente (FREITAS, 1994, p. 218); dos rios navegáveis, ruas, praças. (PEREIRA, 1977, p. 62)

$\mathrm{Na}$ classificação direitos fundamentais/direitos humanos fala-se nas suas dimensões e em suas gerações, quais a primeira, segunda e terceira. Na primeira, situam-se as liberdades públicas (direitos de liberdade, direitos e garantias individuais); os de segunda geração, que são os direitos sociais que representam carências que o Estado supre em benefício da coletividade. E, finalmente, os de terceira geração, cujo sujeito não é nem o indivíduo nem a coletividade, mas o gênero humano: o meio ambiente e o direito das pessoas ao desenvolvimento. Integrando o rol dos direitos fundamentais (caput, art. $5^{\circ}$ da Constituição) a propriedade e com ela a posse ocupam os direitos de primeira geração.

Esse reconhecimento traz imanente a garantia do direito e a ruptura do velho conceito de sujeito passivo nos direitos reais, na propriedade e na posse, pois em decorrência do princípio da função social, os cidadãos têm direito em relação aos titulares do ius in re para que estes cumpram quantum satis a sua utilização em trazer proveitos à coletividade.

Assim como há bens público insuscetíveis de posse por particulares e de sua incidência da usucapião, como o ar atmosférico, o alto mar, terras indispensáveis à defesa das fronteiras, das fortificações e construções militares, das vias federais de comunicação, das áreas de preservação do meio ambiente..., bens que são de todos; bens há ditos comuns do povo, ou de uso especial que não integram esse rol. E não no integram se, na sua concretude, na sua realidade, diante da observação do que ordinariamente sucede, não se destinarem, efetivamente, ao interesse social.

As considerações contrárias à consumação da usucapião de imóveis públicos não levam em conta a usucapião como exercício de direito fundamental, decorrente dos princípios gerais da Constituição. A usucapião nesse contexto tem por objeto a efetividade e concretude da função social da posse, possibilitando o acesso à propriedade, possibilitando a mordia e o plantio, cultivo.

Os bens de uso comum beneficiam qualquer cidadão. Cretella Júnior assinala que "os usuários dos bens de uso comum são o povo" (1969, p. 57).

Os bens comuns de uso do povo e os bens de uso especial apresentam regime jurídico assemelhado, porque ambas as categorias de bens se destinam a concretizar fins públicos e estão afetadas a um fim público relacionado com o uso do bem (ROCHA, 2011, p. 364 - op. Cit.)

Decorrente dessa linha argumentativa, as disposições dos arts. $183, \S 3^{\circ}$ e 191 , Parágrafo Único - CF e as que lhe são similares na infraconstitucionalidade confrontam-se e infringem os objetivos do Estado Democrático de Direito, instituído pela mesma Constituição, mas axiológica e hierarquicamente superiores às disposições meramente literais. Os objetivos ascendem à literalidade. Os valores antepõem-se à formalidade porque aqueles objetivos constituem o "fundamento último da sua não obrigatoriedade esteja na contradição com o direito supralegal".

Assim, os "valores supremos da Constituição fazem, porém, com que toda a infração de direito supralegal, deste tipo, apareça necessária e simultaneamente como violação do conteúdo fundamental da Constituição" (BACHOF, 2007/2014, p.63 - op. Cit.)

E a afirmação de um direito suprapositivo visa a garantir melhor o ser humano contra o Estado. 


\section{À GUISA DE CONCLUSÃO}

Como visto ad nauseam, submetidos os dispositivos constitucionais a uma, interpretação teleológica e sistemática, esmiuçando-lhe os princípios, exsurgirão flexibilizações de preceitos que, se interpretados literal e isoladamente, geram injustiças. Wagner Dias (2000, p. 575-583) argumenta que os bens pertencentes ao Estado são cognominados de "públicos" pela "relevância e utilidade social que possa vir demonstrar." Sustenta mesmo que o bem estatal deve ser revertido de modo benéfico a toda a sociedade, decorrendo daí a especial proteção que lhe dá a Constituição.

Em suma, se a consideração dos fatos e valores extraídos num dado momento histórico permitem a captação do exato significado da norma, jamais houve momento mais propício na história do que se vivencia no País do final do século passado ao alvorecer do século XXI. A moradia e o acesso à terra presentam inconformismo dos movimentos sociais - o que demonstra a conveniência e oportunidade da usucapibilidade dos imóveis públicos que não se submetam à função social.

\section{REFERÊNCIAS}

ALBUQUERQUE, Ana Rita Vieira. Da função social da posse e sua consequência frente à situação proprietária. Editora Lumem Juris, Rio de Janeiro: 2002.

ALFONSIN, Betânia; FERNANDES, Edésio. Direito à moradia e segurança da posse no estatuto da cidade: Diretrizes e processos de gestão. Belo Horizonte: Forum, 2004.

ALMEIDA PRADO, Lídia Reis de. Interdiciplinaridade: O saber com sabor (História de uma influência). In: GONZAGA, Álvaro de Azevedo et al. (Re) Pensando o Direito. São Paulo: Revista dos Tribunais, 2010.

BACHOF, Ozzo. Normas constitucionais inconstitucionais. Trad. José Manuel M. Cardoso da Costa. Coimbra: Almedina, 1994/2007 reimpressão 2014.

BARASSI, Ludovico. Istituzione di diritto civile. Milano: Dott A. Giuffré Editore 1914.

BARROSO, Luís Roberto. Interpretação e aplicação da constituição. $4^{a}$ ed. São Paulo: Sariva, 2002.

BASTOS, Celso Ribeiro. Comentários à Constituição do Brasil (1988). São Paulo: Saraiva, 1990.

BETTI, Emílio. Teoria Generale dela interpretazione. Milano: Dott A. Giuffrè Editire, t.1, 1955.

BOBBIO, Norberto. A era dos direitos (L'etá dei Diretti) trad. Carlos Nelson Coutinho - Rio de Janeiro: Elsevier, 2004, $2^{\mathrm{a}}$ reimpressão.

BUSSADA, Wilson. Código Civil Brasileiro - vol. 3, tomo V - Rio de Janeiro: editora Liber Juris LTDA., 1984. 
CANOTILHO, José Joaquim Gomes de. Direito constitucional e teoria da constituição.

Coimbra: Editora Almedina, 2002.

CANOTILHO, José Joaquim Gomes de. Direito constitucional e teoria da constituição.

Coimbra: Editora Almedina, 1998.

CHAUI, Marilena. O que é ideologia? Coleção primeiros passos, vol. 13, $2^{\text {a }}$ ed. São Paulo: Brasiliense, 2004.

COMTE, Augusto. Systéme de politique positive. Vol. I, edición 1890.

CORTIANO JUNTER, Erouths. O discurso jurídico da propriedade e suas rupturas. Rio de Janeiro: Renovar, 2002.

CRETELLA JÚNIOR, José. Dos bens públicos no direito brasileiro. Monografia para concurso de direito administrativo e ciência da administração da faculdade de Direito da Universidade de São Paulo, 1969.

CRUZ, Álvaro Ricardo de Souza. Hermenêutica Jurídica em Debate: O Constitucionalismo brasileiro entre a teoria do discurso e a ontologia existencial. Belo Horizonte: Editora Forense, 2007. Apresentação de GOMES, Frederico Barbosa.

DE PAGE, Henri. Traité. V. I. 1948, nº 208.

DECICCO, Cláudio. História do direito e do pensamento jurídico. $8^{\mathrm{a}}$ ed. São Paulo: Saraiva, 2017.

DIAS, Wagner Inácio Freitas. Revista Forense, Vol. 352 - ano 96, out./dez., 2000.

DIDIER JR, Fredie. A função social da propriedade e a tutela processual da posse. São Paulo: Revista de Processo: Rep. 133, nº 161, jul. 2008.

DINIZ, Maria Helena. Compendio de introdução à ciência do direito. São Paulo: Saraiva. $26^{\mathrm{a}}$ ed, 2017.

DUGUIT, Leon. Las trasformaciones del derecho publico y privado. Traduccion Adolfo G. Pousada y Ranion Jaen. Buenos Aires: Editorial Heliasta S.R.L. s/d.

DUGUIT, Leon. Les transformation generales du droit prive depuis le code Napoleon. Paris Librarie Felix Alcan, 1912.

FACHINI NETO, Eugênio. A função social no direito privado. In: TIMM, Luciano Beneth et al. Função social do direito. Obra coletiva. São Paulo: Quartier Latirio, 2009.

FERRAZ JÚNIOR, Tércio Sampaio. Introdução ao estudo do direito. São Paulo: Átlas, 1988.

FERREIRA FILHO, Manoel Gonçalves. Princípios fundamentais do direito constitucional. São Paulo: Editora Saraiva, 2010. 
FEYERABEND, Paul. Contra o método. Trad. Cezar Augusto Mortari. São Paulo. Editora Unesp, 2007.

FIUZA, Cesar. Direito Civil. Curso Completo. 16. ed. Belo Horizonte: Del Rey, 2001.

FREITAS, Juarez. A possibilidade de usucapião das terras devolutas em face de uma interpretação teleológica. In: BDA - Boletim de direito administrativo - Abril/1994 .

GADAMER, Hans George. Os traços fundamentais de uma teoria da experiência hermenêutica. In: Verdade e método: traços fundamentais de uma hermenêutica filosófica. 3. ed. Petrópolis: Vozes, 2001.

GIL, Antonio Hernandez. La función social de la posesion (ensayo de la teorización sociológico-jurídica). Alianza editorial S.A., Madrid, 1969.

HOUAISS, Antônio. Dicionário Houaiss da língua portuguesa - Editora Objetiva - Rio de Janeiro. $1^{\text {a }}$ ed, 2009.

JÚNIOR, Humberto Theodoro. Curso de direito processual civil - vol. II, $50^{\mathrm{a}} \mathrm{ed}$. atual ampl. Forense, 2016.

LOPEZ Y LOPEZ, Angel M. La discipliona de la propriedade privada. Madrid, Temo, 1988.

LUSO SOARES, Fernando. Prefácio. IN: RODRIGUES, Manoel. Estudo de direito civil. Ensaio sobre a posse como fenômeno social e instituição jurídica. 4. ed. Coimbra: Livraria Almedina, 1996.

MARQUES, José Frederico. Manual de direito processual civil - Vol. I - 5a ed. 1977. São Paulo: Saraiva.

MIRANDA, Jorge. Manual de direito constitucional. Tomo II, $3^{\text {a }}$ ed. Coimbra: Coimbra Editora, 1991.

MOREIRA, Luiz. A Constituição como simulacro. $2^{\text {a }}$ ed. São Paulo: Editora Contracorrente, 2017.

PEREIRA, Lafayette Rodrigues. Direito das coisas. Vol. I - Edição Histórica. Rio de Janeiro: Editora Rio - Dezembro 1977.

PIMENTEL, Silvia. Apresentação. In: GONZAGA, Álvaro de Azevedo et al. (Re) pensando o direito. São Paulo: Editora Rev. Dos Tribunais, 2010, p. 15.

PONTES DE MIRANDA, Francisco Cavalcante. Tratado de direito privado. São Paulo: Revista dos Tribunais - T. II, 1983.

RESCIGNO, Pietro. Trattato di diritto privado. Proprietá, T.7, Milano: Utet, 1928.

ROCHA, Silvio Luís Ferreira da. Função social da propriedade pública. São Paulo: Malheiros editores, 2005. 
RODRIGUES, Silvio. Direito Civil. 27 ed. rev. e atual. São Paulo: Saraiva, 2002. v. 5: Direito das coisas.

ROSENVALD, Nelson; FARIAS, Cristiano Chaves de. Direitos Reais. Rio de Janeiro: Lumen Juris, $2^{\text {a }}$ ed. 2006.

RUSSEL, Bertrand. História da Filosofia Ocidental e sua conexão política e social desde os tempos primitivos até hoje. 9.ed. Lisboa: Editorial Gleba ltda, 1961.

SARLET, Ingo Wolfgang. Direitos fundamentais sociais, mínimo existencial e direito privado. In: TIMM, Luciano Beneth et al. Função social do direito. Obra coletiva. São Paulo: Quartier Latirio, 2009.

TUPINAMBÁ NASCIMENTO, Miguel de Castro de. A ordem econômica e financeira e a nova Constituição. São Paulo: AIDE, 1989.

WIEACKER, Franz. História do direito privado moderno. 2. ed. 1967 trad. A. M. Botelho Hespanha. Fundação Calouste Gulbenkian - Lisboa, 1967. 